\title{
Fiscal Policy, Public Spending and the 2015
} General Election

Politique budgétaire, dépenses publiques et les élections de 2015

\section{Nicholas Sowels}

\section{OpenEdition}

\section{Journals}

\section{Electronic version}

URL: http://journals.openedition.org/rfcb/528

DOI: $10.4000 / \mathrm{rfcb} .528$

ISSN: 2429-4373

\section{Publisher}

CRECIB - Centre de recherche et d'études en civilisation britannique

\section{Electronic reference}

Nicholas Sowels, «Fiscal Policy, Public Spending and the 2015 General Election », Revue Française de Civilisation Britannique [Online], XX-3 | 2015, Online since 01 December 2015, connection on 19 April 2019. URL : http://journals.openedition.org/rfcb/528 ; DOI : 10.4000/rfcb.528

This text was automatically generated on 19 April 2019

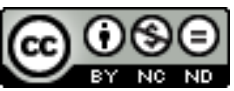

Revue française de civilisation britannique est mis à disposition selon les termes de la licence Creative Commons Attribution - Pas d'Utilisation Commerciale - Pas de Modification 4.0 International. 


\title{
Fiscal Policy, Public Spending and the 2015 General Election
}

\author{
Politique budgétaire, dépenses publiques et les élections de 2015
}

\author{
Nicholas Sowels
}

The general election in May 2015 took place against a fair, but mixed economic background. On the one hand, the UK economy was experiencing quite strong GDP growth, running at a bit more than 2.5 percent on an annualised basis at the time of the vote. This growth rate was similar to pre-crisis levels, and amongst the highest of the industrialised nations. It certainly contrasted with the difficult performance of many Eurozone countries. It also compared favourably with the years of "flat-lining" which the British economy had experienced between 2010 as the Coalition government came to office, through to about the middle of 2013, when growth finally began to pick up. Moreover, the growth performance was accompanied by falling unemployment and very low inflation. Not for nothing did Chancellor George Osborne purr with pride and a bit of French-bashing in his March 2015 Budget Speech, noting that he was not planning to adopt "the French approach" advised by some. ${ }^{1}$

On the other hand, the UK economy was once again manifesting signs of its habitual imbalances. These were most obviously linked to the fact that growth was associated with house price rises, especially in the London area. Indeed, George Osborne had apparently even congratulated himself in Cabinet on this in 2013, noting how he was engineering a good old-fashioned house price boom in the run-up to the election. ${ }^{2}$ Significantly too, household indebtedness continues to be relatively high. In the first quarter of 2015 it stood at 145 percent of disposable household income. ${ }^{3}$ This was considerably lower than the peak of 169 percent in the first quarter of 2008, but was still high by historical standards. Such borrowing, along with continued high public sector borrowing in turn have had their counterpart in a yawning current account deficit, running at 5.5 percent in 2014. Linked to these demand and supply imbalances, which are not particularly new to the UK or even the English-speaking countries as a group, Britain has been suffering from chronic productivity stagnation since the outset of the financial crisis and Great Recession: labour output per hour has been flat for nearly a decade. Lastly, while the 
government deficit was indeed halved during the Parliament, dropping from $10 \%$ of GDP in 2010 to around $5 \%$ at the time of the election, the budget squeeze was far from over (see the table in the Annex for key economic indicators and government finance figures).

The Coalition's economic record going into the general election was therefore mixed, and its track record on bringing down public deficits ambivalent, given its original commitment to more-or-less balancing the budget during the Parliament. As a result, during the 2015 election campaign, the Conservatives pledged to press on with spending cuts and to continuing implementing their plan. Their strong manifesto position may have been an opening bid in possible renewed negotiations with the Liberal Democrats. In the event, they obtained a small parliamentary majority, and immediately began applying quite a strident policy of deficit reduction through spending cuts.

This article starts by examining the Coalition's record on fiscal policy and public spending. It is a controversial record, as we shall see in the first section, but it shaped the background to the election and to the policy of the new Conservative government. Section 2 will then outline the fiscal policy proposals of the main parties during the campaign, and examine in particular how the Conservatives' negative and critical electoral strategy vis-à-vis Labour seems to have been successful. The following section will examine the pursuit of the Conservatives' austerity agenda, notably as put forward in the "emergency budget" of July $2015 .{ }^{4}$ The article concludes by putting forward some considerations about how this policy is likely to evolve and what its results could be.

\section{The Coalition government's record on fiscal policy and public spending}

The Coalition government was formed after the election in May 2010 and immediately announced that it would launch a programme of fiscal consolidation. This turned out to be increasingly controversial as time went on. Yet as growth picked up in the second half of 2013, it became the basis for the Conservative party's electoral platform in 2015.

The background to this overall strategy of fiscal consolidation was the massive development of fiscal deficits in the wake of the 2007-2008 financial crisis and Great Recession. Globally, it is estimated that the financial crisis had led governments to commit \$14 trillion into national banking systems and the international financial system, equivalent to about a quarter of world GDP. ${ }^{5}$ Most of this money was not actually spent, and came in the form of guarantees of bank liabilities which often went unused. Nevertheless substantial sums of public finance were also mobilised and directly injected into banks' capital. In the UK, the government committed $£ 1.2$ trillion to prevent the banking system from collapsing. This sum involved $£ 1,029$ billion in guarantees (not ultimately used) and $£ 133$ billion in direct outlays. Intervention was especially significant in the UK as it was linked to the nationalisation of four major banking groups. As a result of such increased spending (and the contraction of the economy at the end of 2008 and into 2009), total government spending rose to nearly 50 percent of GDP, while tax earnings fell. The overall impact was to push the annual public deficit into double figures. When the Coalition came into office, the public sector deficit was therefore still running at just over 10 percent of GDP.

Such was the background to the Coalition's announcement that it would close the budget gap by the end of the Parliament (in 2015). This policy of consolidation in the UK came at 
a time when European governments were on the whole shifting towards a policy of fiscal austerity, and the economic policy debate was being influenced by warnings concerning the growth consequences of high deficits. In particular, very influential empirical work by two renowned US economists - Carmen Reinhart and Kenneth Rogoff - suggested that once the government debt to GDP ratio rises above 90 percent it has the effect of depressing median growth by 1 percentage point. Their study was based on examining a large number of countries (44) and their debt and growth trajectories over a long period of time (200 years). Its findings were thus based on statistical averages for many different countries, political regimes and economic circumstances. ${ }^{6}$ Therefore, their observation is far from being hard rule or law, universally applicable. Nevertheless, it was a simple finding which could be relatively easily understood and converted into public policy, especially as many industrialised countries were experiencing debt levels at around 90 percent of GDP or more. Britain and other European countries in particular started to cut spending, with an insistence that has undoubtedly played a part in slowing Europe's recovery from the Great Recession, and so arguably compounding the European debt crisis itself.

In this context, the Coalition announced in its "emergency" Budget in June 2010 its intention of bringing the budget deficit down from 10.1 percent of GDP in 2010/11 to 1.1 percent by 2015/16. In its Spending Review presented to Parliament in October 2010, detailed plans were set out to achieve this objective. These plans included an overall reduction in forecast spending of $£ 81$ billion, amounting to a 19 percent cut in spending across all departments, except health and overseas aid.

In the event, the change in policy from supporting growth to squeezing public deficits arguably played an important role in holding down growth in Europe. The situation in Greece has of course been the most acute and socially destructive example in which the pursuit of fiscal austerity has weakened growth, making fiscal consolidation even more difficult. To a far lesser extent, Britain too paid a price for the switch in policy, notably as growth "flat-lined" for more than three years. This even led to a public clash between the government and the IMF in April 2013, when the IMF's Chief Economist Olivier Blanchard warned the British government that it was "playing with fire". ${ }^{7}$ Based on its own research, the IMF and notably Mr Blanchard argued that the world economy following the Great Recession was experiencing an exceptional situation. More specifically, he argued that under the prevailing conditions of low or non-existent growth and very low interest rates, the multiplier of public spending could be significantly greater than 1: in other words, a $\$ 1$ cut in public spending leads to a fall in GDP that is greater than $\$ 1$, and vice versa for increases in spending. ${ }^{8}$ On the basis of this research, the Fund publicly warned the UK government that its pursuit of spending cuts was endangering recovery.

In the face of slow growth, the Coalition government in fact showed itself to be a bit more pragmatic in reality than its rhetoric suggested. Significantly, while repeatedly stating the importance of austerity, it accepted slower deficit reduction than originally planned. But its public presentation of policy remained tough. Part of its approach was based on political calculation, and notably the idea that the deepest retrenchment should be carried out as early as possible, so that a more lenient policy could be adopted in the run up to the 2015 election. Part of the approach was also based on the collective memory of the Conservatives concerning Mrs Thatcher's defiance in the face of the economic slump in the early 1980s - "the Lady is not for turning" - and the insistence with which Mrs Thatcher and Sir Geoffrey Howe (Chancellor of the Exchequer at the time), pushed 
through an austerity budget in the trough of the economic downturn in 1981. In his speech to the Conservative party conference in October 2012, George Osborne very specifically referred to the resolve of this first Thatcher government, whose actions appear subsequently to have been justified. Similarly, with the upturn in growth during the second half of 2013, the Coalition government and George Osborne in particular have felt vindicated in their overall economic plan. In his Budget speech in March 2015, the Chancellor clearly opened by saying, "We took difficult decisions in the teeth of opposition and it worked - Britain is walking tall again". He has also repeatedly noted that the UK has grown "faster than any other major advanced economy in the world".9"

Yet the recent record in growth and employment has surely also been underpinned to quite some extent by unprecedentedly loose monetary policy. The Bank of England's “ Bank rate" has been at 0.5 percent since March 2009. This is an exceptionally low rate which the Bank has maintained for an exceptionally long period of time. In fact, it is completely unprecedented in the Bank's entire history stretching back to 1694 ! Until the end of 2013, the low interest rate was furthermore accompanied by the unconventional policy of "quantitative easing" (QE). This involved the Bank buying financial instruments (largely government bonds) from banks and the markets, in an attempt to push down long term interest rates and so stimulate economic activity. Generally speaking, the impact of these policies is still hard to assess. Both low interest rates and $\mathrm{QE}$ are on the whole believed to have helped in preventing the Great Recession from turning out much worse, but they have not necessarily had quite the impact hoped for, and have likely contributed to new areas of asset-price speculation, while also aggravating income and wealth inequalities. However, for the Conservatives any doubts about macroeconomic policy were not reflected in their election commitments in 2015 and in their subsequent pursuit of strong public spending cuts after the election.

\section{Fiscal policy and public spending in the $\mathbf{2 0 1 5}$ general election}

The election results in 2015 came as a surprise. For months, the opinion polls had been putting the Conservatives and Labour neck-and-neck. It was widely expected and commented that there would be a hung parliament and some form of new coalition. Various combinations of ruling parties were talked about, most notably some new form of coalition between the Conservatives and the Liberal Democrats on the one hand, and some form of coalition or agreement between Labour and the Scottish National Party on the other hand. Other possibilities included a coalition between Labour and the Liberal Democrats, and so on. It is possible that the election manifestos were drafted in view of possible negotiations with potential coalition partners. This was said to be especially so concerning the Conservative manifesto, which was perhaps more extreme than it might have been otherwise, in order to provide room for manoeuvre for the Conservative leadership in bargaining with potential coalition partners. ${ }^{10}$

Whatever the exact calculations may have been, it is sure that the manifesto firmly favoured the continuation of the policy of austerity. Indeed, the Conservative manifesto very clearly stated the aim of reducing public deficits and then running surpluses as of $2018 / 19$, in order to reduce public indebtedness. This turnaround in public finances was to be achieved by departmental savings of $£ 13$ billion, together with further cuts in welfare benefits totalling $£ 12$ billion. According to the manifesto, an additional $£ 5$ billion 
was to be saved by tackling tax evasion, bringing the total spending consolidation to $£ 30$ billion. Also, the manifesto set out the Conservatives' objective of reducing administrative expenditure by $£ 1$ for every $£ 100$ spent, during the first two years of office. Tellingly, it notes that "[w]e don't think there is a business that couldn't do that". ${ }^{11}$

The Conservatives pledged to achieve these fiscal adjustments - and the return to public sector surpluses towards the end of the Parliament - through spending cuts, while ruling our tax increases. The manifesto made a specific commitment not to raise VAT, National Insurance Contributions or income tax. In fact, at the end of April 2015, David Cameron even went so far as to commit a future Conservative government to pass a law prohibiting tax increases in these areas. This was an unusual proposition in as much as it seeks to bind future government policy discretion by formal legislation. As even (Lord) Nigel Lawson has noted, the pledge would limit George Osborne's capacity of raising government revenue in a way that no "previous Chancellor" would have done. ${ }^{12}$

Fiscal responsibility also featured in the Labour party's manifesto, entitled Britain can be better. It is notable that in the preamble to the document itself, Labour committed itself to establishing a "Budget Responsibility Lock", based on reducing the public sector deficit every year, and achieving a budget surplus by the end of the Parliament. More specifically, the manifesto stated that the Labour party had no new spending or borrowing plans: "[a]ll of our commitments will be paid for by reducing spending elsewhere or by raising extra revenue. For example, we will introduce a tax on properties worth over $£ 2$ million to help raise the $£ 2.5$ billion a year for an NHS Time to Care Fund - part of our plan to save and improve the health service". ${ }^{13}$

The Labour party manifesto also proposed making richer households pay more in taxation, while reducing their welfare benefits. Thus, it included a commitment to restore the top income tax rate to 50 percent, for the top 1 percent of earners, with incomes of more than $£ 150,000$. At the same time, the manifesto pledged to stop paying Winter Fuel Payments to the top 5 percent of households, while capping child benefits. In fact, the manifesto went so far as to commit the party to cap structural social security expenditure in each spending review. The document also committed the party to using proceeds from the privatisation of Lloyds bank and the RBS to pay back national debt.

The Labour party's election pledges appear generally to have been quite detailed and cautious. This reflects the legacy of New Labour's and Gordon Brown's previous commitments to "prudence", and the generally mainstream approach to economics of Ed Balls. Mr Balls was the principle economic policy advisor to Gordon Brown during the opposition years in the 1990s and then during most of New Labour's first two periods in government (1997-2001 and 2001-2005). Subsequently, Ed Balls was shadow Chancellor throughout Ed Miliband's time as leader of the Opposition. Labour's broadly cautious approach to fiscal policy was also a way of trying to present itself as economically responsible, especially given the poor support the party was getting from business. ${ }^{14}$

However, Labour failed to be as convincing as the Conservatives on the economy. Two factors stand out in particular: first the hostility between Labour and business and second Labour's inability to be persuasive enough concerning government spending. The former is not really within the scope of this article, but it should be noted that during its years in opposition, Labour and Ed Miliband had made a number of pronouncements and policy proposals that were interpreted as anti-business and regulatory. For example, at the 2011 party conference Mr Miliband had criticised "predators" who were "interested in the fast buck", etc. Similarly, proposals for "fixing broken markets", freezing energy prices and so 
on appear to have been clearly interpreted by business as being interventionist. ${ }^{15}$ Offsetting this was, however, Labour's far more pragmatic position on European Union membership. Prior to the election, the party had ruled out holding a referendum, and during the campaign made a point of stressing that the Conservative commitment to a referendum would plunge businesses into a long period of uncertainty before the vote, and even afterwards in case of a vote to leave the EU.

Turning to public spending, the Labour Party and Ed Miliband personally failed to counter Conservative criticisms of the previous Labour government and in particular the policies of Gordon Brown in controlling public spending. Indeed, during the Coalition and then the election campaign, the Conservatives managed to portray their successors as having been reckless with public finances. Although government spending as a share of GDP was not particularly high at the start of the financial crisis in (42.6 percent of GDP in 2006, see the Annex), the Conservatives skilfully obfuscated the fact that the explosion of deficits and public sector debt in the closing years of the Labour government were largely due to the financial crisis and hardly a direct result of old-Labour tax and spend policies. A particularly damaging moment came in the closing days of the election campaign in the live Question Time debate on the BBC, on Thursday the 30 April, a week before the poll. During the programme, David Cameron, Ed Miliband and Nick Clegg were each questioned by an audience on all areas of policy. In the words of Guardian columnist Jonathan Freedland:

...the most lethal missile of the night came from the man who asked whether Miliband would admit that the last Labour government had overspent. When the Labour leader said no, a lowing sound could be heard, the noise of an audience uniting in sceptical rejection of the man before them. ${ }^{16}$

For Labour grandee, Alan Johnson, writing the day after the 7 May election, this was a turning point in the campaign when, "[t]he public became convinced that Labour had indeed driven the car into the ditch and declined to return the keys". ${ }^{17}$

The Liberal-Democrats' manifesto - running to nearly 160 pages! - also put fiscal responsibility right at the top of its agenda. The manifesto started by running on the Party's record as a coalition partner, and noting how the annual deficit had been halved between 2010 and 2015. In contrast to the Conservatives, the Liberal-Democrats stressed the importance of (some) tax rises to balance the books by 2017/18. They very clearly positioned themselves as standing between the Conservative policy of relying only on public spending cuts to bring down deficits, and Labour's greater recourse to taxation to close the budget gap. Notably, however, the manifesto did not indicate which taxes would be raised (or created), and stated that "headline taxes" like income tax, VAT, National Insurance and Corporation Tax should not be increased. The manifesto also pledged the Lib-Dems to cut taxes for poorer households by raising the tax-free Personal Allowance (i.e. the threshold below which individuals or households do not pay tax). ${ }^{18}$

Alongside their general commitment to balance the books, the Liberal Democrats proposed two new rules by which fiscal policy and public finances were to be guided. Their first rule was that once the budget deficit was closed in 2017/18, public sector debt as a share of GDP should fall each year, except during recessions. The aim was for debt to reach "sustainable levels around the middle of the next decade". The second rule was to balance public spending over the "economic cycle", apart from finance for investment, provided the debt rule is met: "the government will be able to borrow for capital spending that enhances economic growth or financial stability, enabling us to increase this productive 
investment". This latter rule was very similar to New Labour's Golden Rule for fiscal policy, put forward in its 1997 manifesto, and then adopted when in government. This is not the place to discuss the usefulness and feasibility of fiscal rules. Suffice it to say, however, that the New Labour governments had already broken the Golden Rule to finance public services in the mid-2000s, prior to the haemorrhaging of public finances during the financial crisis. Similarly, governments of the Eurozone, though they too have repeatedly committed themselves to rules-based fiscal policy, have also repeatedly broken their own rules. In short, announcing fiscal rules sounds fine in principle, but frequently turns out to be more difficult to apply in practice over time, especially when circumstances change.

The case of the Scottish Nationalist Party (SNP) manifesto is somewhat different. Unlike the other manifestos, it specifically argued for supporting public services but in Scotland. As the manifesto's title - Stronger for Scotland - and the party's exclusive representation in Scotland both suggest, the SNP's approach to the election was based overwhelmingly on getting the best funding deal for Scotland. The manifesto said little about the whole of the UK, although its preamble did argue that the Scottish Nationalists want "to help deliver positive change for the benefit of ordinary people, not just in Scotland, but across the UK". Accordingly, the manifesto preamble went on to declare that:

We propose a real alternative to the pain of austerity, an end to unfair policies like the Bedroom Tax, a higher minimum wage and protection for our NHS and vital public services. Instead of even deeper Westminster spending cuts, we want to see more investment in our economy, to create more and better paid jobs. ${ }^{19}$

The SNP manifesto did therefore contrast quite strongly with the manifestos of the three main national parties presented above. It very clearly opposed "austerity", and proposed tackling deficit reduction not through spending cuts, but by raising taxes, including: "the reintroduction of the 50 pence top tax rate, a tax on bankers' bonuses, a bank levy, a mansion tax, a crackdown on tax avoidance, the abolition of 'non-dom' status and reversal of the married couple's tax allowance". While supporting the policy of debt reduction, the SNP manifesto nevertheless argued that such tax increases would provide " 1140 billion across the UK to invest in skills and infrastructure, in our NHS and other public services, and in measures to protect the vulnerable and lift people out of poverty". In contrast to the other manifestos, the SNP therefore argued far more forcefully for expanding welfare and public services, financed through higher taxation.

Lastly, the UKIP manifesto was broadly based on a tax cutting and spending reduction agenda, in that order. Accordingly, its key proposals included: raising the personal allowance to at least $£ 13,000$ during the forthcoming parliament; abolishing inheritance tax - a "death tax" which "hits the middle classes hardest"; raising the 40 percent income tax threshold, and introducing an intermediate 30 percent rate for "middle-income earners such as school teachers and senior nurses" who should not be paying the top rate. The overall aim of tax policies was to bring down income taxes as a whole, while making the tax structure flatter. On the spending side, the UKIP manifesto begins by stressing that leaving the EU would cut public spending by $£ 9$ billion (the UK's net contribution to the EU budget). It also proposed a significant cut in overseas aid, down from the international target of 0.7 percent of gross national income, to 0.2 percent ("matching the contribution made by the USA"). The manifesto went on to put forward an end to the Barnett Formula for calculating Scotland's block grant from the UK's national budget. According to UKIP, this would lead to "substantial reductions in funding for Scotland", though the Scottish parliament would be able to make its own decisions on taxation in Scotland. Finally, the UKIP manifesto set out a number of areas for cutting direct government spending, such as 
reducing the size of the House of Commons, abolishing certain government departments, abolishing unnecessary quangos, "ceasing all subsidies for bars and dining rooms in the Palace of Westminster", etc. ${ }^{20}$ In short, the tax and spending agenda of UKIP stood out as rightwing, nationalist and quirky, in the image of Nigel Farage himself.

\section{Fiscal policy and government spending following the Conservative election victory}

To widespread surprise, the Conservatives won the election, with a small outright majority. With 36.9 percent of the vote (on a turnout of 66.1 percent), the Conservatives took a total of 330 seats, giving them a working majority of 12 seats. 11.3 million electors voted for the party. This contrasts with the last Conservative government to be reelected, by a small margin of seats: in 1992, John Major led the Tories to victory, winning a 21-seat majority, on the basis of 41.9 percent of votes cast, and an absolute historic record number of votes totalling 14.1 million.

The unexpected success by the Conservatives in 2015 has been much attributed to campaign strategy of Lynton Crosby, their Australian electoral consultant. This is not the place to examine the strategy in detail, but it is worth looking at a couple of related issues. One has already been mentioned above, namely the success the Conservatives had in labelling Labour as having been reckless with public spending when last in power. The second involves the so-called technique of "wedge-politics" whereby one camp (in this case the Conservatives) seeks to split its opponent's traditional supporters. Thus, Mr Crosby apparently - correctly - identified the rise of Scottish nationalism as a wedge to be used against Labour, both in Scotland and England. ${ }^{21}$ By repeatedly stressing the economic consequences and above all the impact on the Union of some form of alliance between Labour and the SNP, the Conservatives skilfully divided and conquered their enemies. During the closing days of the campaign, Ed Miliband was boxed into ruling out emphatically any possible governing agreement with the SNP. Along with his poor performance concerning the New Labour record (see above), this made it hard for the Labour party to appear credible in terms of forming a new (coalition) government. Putting it in more conventional terms, and reiterating his view that the Conservative party dominates British electoral politics because of "fear", Vernon Bogdanor commented that "[f]ear of Labour's economic policies and of an SNP stranglehold at Westminster were sufficient to see David Cameron comfortably home". ${ }^{22}$

The unexpected nature of the Conservative victory in 2015 seems to have given David Cameron's new government the impression of having received a strong and clear mandate, to push through quite radical and often controversial measures. Most notably, the Conservatives will honour their electoral pledge to hold a referendum on EU membership by the end of 2017. This is a radical policy commitment that has been much in the news since the election, and the Labour party has subsequently agreed to support the organisation of a referendum. More contested, however, has been the new government's decision to press ahead with the repeal of the Human Rights Act 1988, a kind of sop to the Eurosceptics in the party. The Act incorporates the European Convention of Human Rights (ECHR) into British law, and even though the Convention is not an emanation of the EU it seems to suffer from guilt by association. At the time of writing (July 2015), the nature of reform in this area remains open, partly due to the fact that senior Conservative politicians have openly defended the link to the ECHR, noting 
amongst other things that former Tory grandee and Lord Chancellor David Maxwell Fyfe had played a key role in drafting the Convention in 1950.

The same cannot be said about public spending. If the Conservative manifesto was indeed written as a kind of opening bid in view of possible negotiations with the Lib-Dems as a renewed coalition partner, George Osborne has been quick to implement its promises of spending cuts, including $£ 12$ billion in cuts to welfare. Indeed, a week after the election, he announced in The Sun that he would put a second emergency budget to Parliament in early July (2015), in order not to wait to tackle the problem of Britain's budget deficits. ${ }^{23}$

Accordingly, on 8 July the Chancellor presented his second budget for the year to the House of Commons. Ostensibly trailed as a budget for "working people", George Osborne set out the government's vision of creating a "new settlement" based on "a plan for Britain for the next 5 years to keep moving us from a low wage, high tax, high welfare economy; to the higher wage, lower tax, lower welfare country we intend to create". To this end, George Osborne announced the introduction of a National Living Wage - drawing on the idea promoted by the campaign of the Living Wage Foundation and the Labour party for a more decent minimum wage - and he stated that it would rise to $£ 9$ an hour by 2020 . This was accompanied by an announced rise of personal allowances to $£ 11,000$ by $2016 / 7$, and an increase in the threshold for entering the 40 percent top income tax bracket to $£ 43,000$.

In contrast and revealingly, Mr Osborne also pushed back the schedule for reaching a budget surplus by one year, to 2019/20. This can be viewed as another manifestation of his somewhat more pragmatic practice compared to his tougher policy statements.

At the same time, however, the Chancellor announced a series of measures to squeeze welfare spending by $£ 12$ billion. Most notably, these include: a reduced cap on welfare payments that any one household can obtain (down to $£ 23,000$ per year in London and $£ 20,000$ in the rest of the country); and a significant change in the operation of tax credits and other support for people in work. In particular, the income levels at which such credits are paid will be lowered, and the increase in credits is frozen. According to an early estimate given by the Director of the Institute of Fiscal Studies, the freezing of credits will affect 13 million families, costing them an average of £260 per year; while the drawing down of the allowance will lead to an average $£ 1,000$ fall in the incomes of 3 million families. ${ }^{24}$

Apart from the specific measures put forward to cut welfare spending, George Osborne's presentation of welfare as such is very revealing. Paraphrasing an expression often used by the German Chancellor Angela Merkel, Mr Osborne noted in his budget speech that " Britain is home to $1 \%$ of the world's population; generates $4 \%$ of the world's income; and yet pays out $7 \%$ of the world's welfare spending". ${ }^{25}$ Very significantly he went on to say that "It is not fair to the taxpayers paying for it". In making such a strong assertion, he has very clearly reflected the success which neoliberals have had in arguing that "welfare" is a burden on employed taxpayers. Initially in the first phases of neoliberalism in the 1980s, this strategy was based on the alleged inefficiencies of providing welfare benefits and services to the middle class, rather than letting them take out various forms of private insurance. ${ }^{26}$ Subsequently, once welfare is pared back to support a (poor) minority, it can then be recast not as universal social insurance for all - Beveridge's original vision - but as a burden on the self-reliant who are in gainful employment. The emergency budget makes this point unequivocally.

To be sure, the July Budget also announced some measures to end so-called "non-dom" status (i.e. the ability to claim non-residence status and hence tax exemption) for people 
living permanently in the United Kingdom. Similarly, new measures and enhanced resources to collect taxes are forecast to generate $£ 5$ billion in revenue through reductions in tax avoidance. Yet the ideological orientation of the budget is not to be mistaken. This is especially so given that Mr Osborne also announced that corporation tax will be reduced to 18 percent by 2020 , following the substantial reduction from 28 percent to 20 percent which occurred in the last Parliament (2010-2015)!

In short, the Budget and the new government's overall policy approach is strongly neoliberal and indeed neo-Thatcherite. It fits in with the government's other policies, for example the revival of tenants' Right to buy their homes from housing associations as well as from local councils, and the further tightening of legislation regulating strike action. At the time of writing (July 2015), Mr Osborne and the government feel largely vindicated in their overall economic strategy. Britain's headline growth figures are good (second quarter growth was 0.7 in 2015, up to the pre-crisis growth rate, with unemployment still falling and inflation flat). Whether the government's economic policies are enough to tackle the on-going structural problems of the UK economy, however, is another question.

\section{Conclusion}

The election campaign was led by the Conservatives and the other major parties in the expectation that the electorate would once more return a hung parliament to Westminster. It is therefore possible that the manifestos of the leading parties, whose public spending commitments have been presented here, were to some extent drafted in view of holding negotiations to form a new coalition government. They may be seen, to some extent at least, as constituting opening positions prior to coalition discussions. Policies could then have been watered down during negotiations. It is important to note from this point of view, that the three major parties (the Conservatives, Labour, and the Lib-Dems) all placed a high priority on bringing down public deficits, though for the Conservatives this is to be done through spending cuts.

In the event, the Conservatives obtained a small outright majority in the House of Commons, based on a relatively low share of the total electorate, and a relatively low absolute popular vote. They nevertheless immediately set out to implement their agenda in full, which in the case of public spending includes planned cuts in welfare spending running to $£ 12$ billion. The stated aim is to close the existing deficit gap, which was still over 5 percent of GDP in 2014, and generate a budget surplus by 2019/20.

The recovery in the British economy since the second half of 2013 is seen and presented by the Conservatives as a clear indication that their strategy - their "plan" - is working. While "austerity" may have contributed to the flat-lining between 2010 and early 2013, the more recent pick-up in growth has confirmed the Conservatives' view that the contractionary consequences of squeezing public spending are not to be worried about, as was already shown dramatically in the past by the 1981 budget squeeze which in fact took place at a time when Britain was beginning to come out of its early-1980s slump. The bet today is that Britain is in a broadly similar position. In fact, both the new government's fiscal policy (the squeeze on spending) and other policies like the revival of Right-to-Buy, the further curtailment of trade union striking rights, the Eurosceptic stance of the government and especially the upcoming referendum on EU membership are all markedly neo-Thatcherite. 
But 2015 is not 1979, and neither Britain nor the rest of the industrialised world is embarking on creating the neoliberal paradigm. Quite the contrary, more than three decades of neoliberal policies have left the UK economy with a number of structural imbalances, including most notably the domination of international finance, repeated house-price booms and busts, deepening inequality (especially wealth inequality), everretrenching manufacturing and low labour productivity. Both the Conservative election manifesto and the policies implemented in the July 2015 Budget, as well as those likely to follow in the autumn spending review are unlikely to tackle these structural weaknesses. Thus while the UK economy is indeed benefitting from relatively strong growth at the time of writing (July 2015), it may well be asked whether such growth is not in fact much linked to the historically-unparalleled monetary boost it has received for more than five years: interest rates have been much lower and for longer than at any previous time of the Bank of England's 320-year history. If the 1970s are often portrayed as the decade when Keynesianism spun wholly out of control, it may today be asked whether the same cannot be said for how cheap money is being used to stimulate growth. Also, unlike the mid-1980s (or indeed the mid-1990s and mid-2000s) when the US economy was roaring out of recession and other parts of the world economy were booming, today's external environment is considerably more fragile. Moreover, many of the underlying weaknesses of the international financial system have not really been dealt with. This raises the question of whether the rather simplistic and repeated policy mix being applied by the new Conservative government is really sufficient to ensure a return to more balanced growth, let alone to help generate a more equitable distribution of the fruits of growth.

\section{BIBLIOGRAPHY}

ALESSANDRIE, Piergiorgio \& HALDANE, Andrew. "Banking on the State", Paper, Bank of England, 6 November 2009, <http://www.bankofengland.co.uk/archive/Documents/historicpubs/ speeches/2009/speech409.pdf>, retrieved 18 August 2015.

BECKETT, Andy. "Lynton Crosby: the man who really won the election for the Tories", The Guardian, 8 May 2015.

BLANCHARD, Olivier \& LEIGH, Daniel. "Growth Forecast Errors and Fiscal Multipliers", IMF Working Paper, 13/1, at <https://www.imf.org/external/pubs/ft/wp/2013/wp1301.pdf>, retrieved 30 July 2015.

BURKE, Michael. "If the IMF is criticising UK austerity, things must be bad", The Guardian, 17 April 2013.

CONSERVATIVE PARTY, The Conservative Party Manifesto 2015, April 2015.

ELLIOT, Larry. "George Osborne calls emergency July budget to reveal next wave of austerity", The Guardian, 16 May 2015.

FREEDLAND, Jonathan. "Question Time crowd emerge as stars on a night of vicious attacks on leaders, The Guardian, 30 April 2015.

Revue Française de Civilisation Britannique, XX-3 | 2015 
GAPPER, John. "UK election 2015: Labour strains”, The Big Read, The Financial Times, 30 March 2015.

HOUSE OF COMMONS LIBRARY. Household Debt: Key Economic Indicators, Research Briefings, 29 July 2015, at: <http://researchbriefings.parliament.uk/ResearchBriefing/Summary/SN02885>, retrieved 30 July 2015.

JOHNSON, Alan, "When that Question Time audience turned on Ed Miliband, the die was cast", The Guardian (online), 8 May 2015.

JOHNSON, Paul. Opening remarks, Institute for Fiscal Studies, Summer post-Budget briefing 2015, 9 July, available at: <http://www.ifs.org.uk/uploads/publications/budgets/Budgets\%202015/ Summer/opening_remarks.pdf>, retrieved 29 July 2015.

KEEGAN, William. Mr Osborne's Economic Experiment, Searching Finance, 2014.

LABOUR PARTY. Britain can better: Labour Party Manifesto 2015, 2015.

LIBERAL DEMOCRATS. Manifesto 2015 Stronger Economy, Fairer Society, Opportunity for Everyone., 2015.

MORRIS, Nigel and WRIGHT, Oliver. "General Election 2015: The masterminds behind the scenes", The Independent, 31 March 2015.

NARDELLI, Alberto. "Does the UK really have 7\% of the global welfare spend?", The Guardian, 17 June 2015.

OSBORNE, George. Budget Speech, 18 March 2015.

OSBORNE, George. Budget Speech, 8 July 2015.

RAWNSLEY, Andrew. "Party manifestos: furtive silences that speak more eloquently than flowery words", The Observer (Guardian website), Sunday 12 April 2015.

REINHART, Carmen \& ROGOFF, Kenneth. "Debt and growth revisited", 11 August 2010, VOX, CEPR's Policy Portal, at: < http://www.voxeu.org/article/debt-and-growth-revisited>, retrieved 30 July 2015.

SCOTTISH NATIONALIST PARTY. Stronger for Scotland, Manifesto, 2015

SNOWER, Dennis. “The Future of the Welfare State”, Economic Journal, no 101, May 1993, pp 700-717.

UKIP. Believe in Britain, UKIP Manifesto, 2015.

WHALE, Sebastian. "Lord Lawson criticizes Tory tax freeze pledge", Politics Home, 27 May 2015, $<$ https://www.politicshome.com/party-politics/articles/story/lord-lawson-criticises-tory-taxfreeze-pledge>, retrieved 18 August 2015.

\section{NOTES}

1. George OSBORNE, Budget Speech, 18 March 2015. Although he was not very specific about this, Mr Osborne was presumably referring to suggestions by the IMF that the government should do more to support demand through higher spending: see Section 1 of the article.

2. William KEEGAN, Mr Osborne's Economic Experiment, Searching Finance, 2014, p. 97.

3. HOUSE OF COMMONS LIBRARY, Household Debt: Key Economic Indicators, Research Briefings, 29 July 2015, at: <http://researchbriefings.parliament.uk/ResearchBriefing/Summary/SN02885>, retrieved 30 July 2015. 
4. An "emergency budget" refers to a budget implemented by an incoming government so that it can immediately apply its policies.

5. Piergiorgio ALESSANDRIE, and Andrew HALDANE, Banking on the State, Paper, Bank of England, 6 November 2009, <http://www.bankofengland.co.uk/archive/Documents/historicpubs/ speeches/2009/speech409.pdf>, retrieved 18 August 2015.

6. For a summary presentation of their findings see: Carmen REINHART and Kenneth ROGOFF, "Debt and growth revisited", 11 August 2010, VOX, CEPR's Policy Portal, at: < http:// www.voxeu.org/article/debt-and-growth-revisited>, retrieved 30 July 2015.

7. The expression was widely reported, including by Michael BURKE, "If the IMF is criticising UK austerity, things must be bad", The Guardian, 17 April 2013.

8. Olivier BLANCHARD and Daniel LEIGH, "Growth Forecast Errors and Fiscal Multipliers", IMF Working Paper, 13/1, at <https://www.imf.org/external/pubs/ft/wp/2013/wp1301.pdf>, retrieved 30 July 2015.

9. This point was made by George Osborne in his Budget Speech on 18 March 2015, and more or less repeated in his emergency Budget Speech on 8 July 2015.

10. Andrew RAWNSLEY, "Party manifestos: furtive silences that speak more eloquently than flowery words", The Observer (Guardian website), Sunday 12 April 2015.

11. CONSERVATIVE PARTY, The Conservative Party Manifesto 2015, April 2015.

12. As reported by Sebastian WHALE, "Lord Lawson criticizes Tory tax freeze pledge", Politics Home, 27 May 2015: <https://www.politicshome.com/party-politics/articles/story/lord-lawsoncriticises-tory-tax-freeze-pledge>, retrieved 18 August 2015.

13. LABOUR PARTY, Britain can better: Labour Party Manifesto 2015, 2015.

14. Nigel MORRIS and Oliver WRIGHT, "General Election 2015: The masterminds behind the scenes", The Independent, 31 March 2015.

15. John GAPPER, “UK election 2015: Labour strains”, The Big Read, The Financial Times, 30 March 2015.

16. Jonathan FREEDLAND, "Question Time crowd emerge as stars on a night of vicious attacks on leaders, The Guardian, 30 April 2015.

17. Alan JOHNSON, "When that Question Time audience turned on Ed Miliband, the die was cast", The Guardian (online), 8 May 2015. The debate can be viewed online at: <https:// www.youtube.com/watch?v=Ek062GheJgQ>, retrieved 27 July 2015. The exchanges between Ed Miliband and members of the audience asking him questions about Labour's previous spending record occur between minutes 38 and 42 .

18. LIBERAL DEMOCRATS, Manifesto 2015 Stronger Economy, Fairer Society, Opportunity for Everyone, 2015.

19. SCOTTISH NATIONALIST PARTY, Stronger for Scotland, Manifesto, 2015.

20. UKIP, Believe in Britain, UKIP Manifesto, 2015.

21. Andy BECKETT, "Lynton Crosby: the man who really won the election for the Tories", The Guardian, 8 May 2015.

22. Vernon BOGDANOR, "Fear of Labour's policies and SNP trump hope in UK election", The Financial Times, May 10, 2015.

23. Reported by Larry ELLIOT, "George Osborne calls emergency July budget to reveal next wave of austerity”, The Guardian, 16 May 2015.

24. Paul JOHNSON, Opening remarks, Institute for Fiscal Studies, Summer post-Budget briefing 2015, 9 July, available at: <http://www.ifs.org.uk/uploads/publications/budgets/Budgets\% 202015/Summer/opening_remarks.pdf>, retrieved 29 July 2015.

25. Angela Merkel has frequently been reported noting that "Europe has 7\% of the world's population, $25 \%$ of its wealth, $50 \%$ of its welfare spending" (quoted here by Alberto NARDELLI, "Does the UK really have 7\% of the global welfare spend?", The Guardian, 17 June 2015. 
26. One very clear presentation of this argument, which broadly fits into the public choice criticism of public policy and public services, was given by the American academic Dennis SNOWER in "The Future of the Welfare State", Economic Journal, 1993, n 101, May, pp. 700-717.

\section{ABSTRACTS}

The general elections in May 2015 took place against a fair, but mixed economic background. After three years in the previous parliament when the UK economy had been flat-lining (mid-2010 to mid-2013), partly as a result of the Coalition's policy of fiscal consolidation, the pick-up in activity during the second half of 2013 provided the outgoing government with a reasonable economic record to present to the electorate. The three main parties - the Conservatives, the Liberal Democrats and Labour - all ran manifestos based on fiscal responsibility, as in some ways did UKIP. Only the SNP proposed a clearer leftwing agenda based on stronger public services and higher taxation. Given the outcome of the elections, the Conservatives appear to have had a more successful electoral strategy, in which they succeeded in portraying themselves as economically competent while characterising Labour as having wrecked the economy during the Blair-Brown years. Yet the economy was not the only major issue to have shaped the electoral results. Since resuming office unexpectedly, the Conservatives have pursued the policy of deficit and debt reduction begun under the Coalition, as part of a tougher neo-Thatcherite approach.

Les élections ont eu lieu en mai 2015 dans un contexte économique relativement favorable, quoique mitigé. Pendant les trois premières années de la législature précédente (de mi-2010 à mi-2013), l'économie britannique marquait le pas, partiellement en raison de la politique d'austérité budgétaire du gouvernement de Coalition. Puis, à partir du second semestre de 2013, l'économie entre dans une nouvelle phase de croissance. Ainsi le gouvernement sortant pouvait présenter un bilan économique raisonnable à l'électorat. Les trois principaux partis - les conservateurs, les libéraux-démocrates et les travaillistes - ont tous élaboré des manifestes électoraux fondés sur la responsabilité budgétaire. Il en va de même pour UKIP. Seulement le SNP a proposé une plateforme qui était clairement à gauche, comportant le renforcement des services publics et une imposition plus élevée. Compte tenu des résultats des élections, la stratégie électorale des conservateurs semble avoir réussi, notamment en soutenant que les travaillistes avaient ruiné l'économie britannique pendant les années Blair-Brown. Pourtant, l'économie était loin d'être la seule question qui a déterminé les résultats électoraux. Depuis leur réélection et grâce à une majorité parlementaire inattendue, les conservateurs ont poursuivi la politique de réduction des déficits et des dettes publiques commencée sous la coalition, mais d'une manière bien plus dure et néo-thatchérienne.

\section{INDEX}

Mots-clés: Royaume-Uni, élections générales, gouvernement de coalition, Parti conservateur, politique budgétaire, dépenses publiques

Keywords: United Kingdom, general elections, coalition government, Conservative party, fiscal policy, public spending 
AUTHOR

NICHOLAS SOWELS

Université Paris 1 